\title{
Gold-iridium catalysts for the hydrogenation of biomass derived products
}

\author{
Lorenzo Landenna a, Alberto Villa a , Rodolfo Zanella b, Claudio Evangelisti c, Laura Prati a,* \\ a Dipartimento di Chimica, Università degli Studi di Milano, Via C.Golgi 19, 20133 Milano, Italy \\ b Centro de Ciencias Aplicadas y Desarrollo Technologico, Universidad Nacional Autonoma de Mexico, Mexico City 04510, Mexico \\ c Istituto di Scienze e Tecnologie Molecolari ISTM-CNR, Via G. Fantoli 16/15, 20138 Milano, Italy
}

\section{A R T I C L E I N F O}

\section{Article history:}

Received 11 May 2016

Accepted 9 July 2016

Published 5 October 2016

\section{Keywords:}

Levulinic acid hydrogenation

Gold-irdium catalyst

Gold-ruthenium catalyst

$\gamma$-Valerolactone

Synergistic effect

\begin{abstract}
A B S T R A C T
$\mathrm{Au}-\mathrm{Ir}$ and $\mathrm{Au}-\mathrm{Ru}$ on $\mathrm{TiO}_{2}$ catalysts prepared by sequential deposition-precipitation technique were compared with the corresponding monometallics in the hydrogenation of levulinic acid to $\gamma$-valerolactone. Interestingly the addition of $\mathrm{Au}$ to $\mathrm{Ir} / \mathrm{TiO}_{2}$ showed a detrimental effect on the activity of Ir monometallic catalyst whereas a positive synergistic effect was shown in the case of Ru. Both catalysts were reduced under $\mathrm{H}_{2}$ to increase the $\mathrm{M}^{0}-\mathrm{Au}^{0}$ interaction. From previous DFT calculations and catalytic test, we addressed the lower activity of $\mathrm{Au}-\mathrm{Ir} / \mathrm{TiO}_{2}$ than that of $\mathrm{Ir} / \mathrm{TiO}_{2}$ to the interference of $\mathrm{Au}$ into the redox mechanism of Ir atoms.
\end{abstract}

(C) 2016, Dalian Institute of Chemical Physics, Chinese Academy of Sciences. Published by Elsevier B.V. All rights reserved.

\section{Introduction}

$\gamma$-Valerolactone (GVL) has been identified as a potentially sustainable platform molecule for the production of renewable fuels and fine chemicals [1-6], and its production is mainly based on the hydrogenation of levulinic acid (LA), which can be directly obtained from cellulosic materials by acidic hydrolysis [1]. A cascade reaction involving hydrogenation and dehydration steps takes place (Scheme 1) under acidic conditions in the presence of metallic catalysts. On this topic a lot of studies have been carried out $[7,8]$ in particular on $\mathrm{Ru}[9]$ or $\mathrm{Cu}[10]$ supported on activated carbon (AC) or oxidic supports in different solvents, such as water or alcohols [4-6] and dioxane [11,12]. The addition of acidic co-catalyst, such as niobium phosphate or oxide, to $\mathrm{Ru} / \mathrm{AC}$ [13] or the use of acidic carbons [14] has been shown to speed up the reaction rate under mild reaction conditions $\left(70{ }^{\circ} \mathrm{C}, 0.3 \mathrm{MPa}\right.$ of $\left.\mathrm{H}_{2}\right)$, keeping a selectivity $>98 \%$ towards the GVL product. This result has been attributed to the promotional effect of the acidic sites on the dehydration step (Scheme 1).

The major limitation of most of the heterogeneous catalysts applied in this reaction is the low stability and in this respect the addition of $\mathrm{Au}$ to $\mathrm{Ru} / \mathrm{AC}$ with the formation of a bimetallic phase appeared essential from both activity and durability point of view [15]. The synergistic effect between $\mathrm{Au}$ and $\mathrm{Ru}$ diffusion within the Ru particles. However, it was not possible to disentangle any electronic effects or improved metal-support interaction could not be excluded.

Ir-based catalysts have been poorly investigated in this reaction and only a few reports deals with heterogeneous systems showing that $\mathrm{Ir} / \mathrm{SiO}_{2}$ is poorly active and also poorly selective to GVL [16]. It became active (but not selective) only when Mo is added as modifier. Soluble Ir complexes, however, has been addressed to an alloyed phase due to the Au atom

\footnotetext{
* Corresponding author. Tel: +39 02503 14357; Fax: +39 02503 14405; E-mail: Laura.Prati@unimi.it

DOI: 10.1016/S1872-2067(16)62512-3 | http://www.sciencedirect.com/science/journal/18722067 | Chin. J. Catal., Vol. 37 , No. 10, October 2016
} 


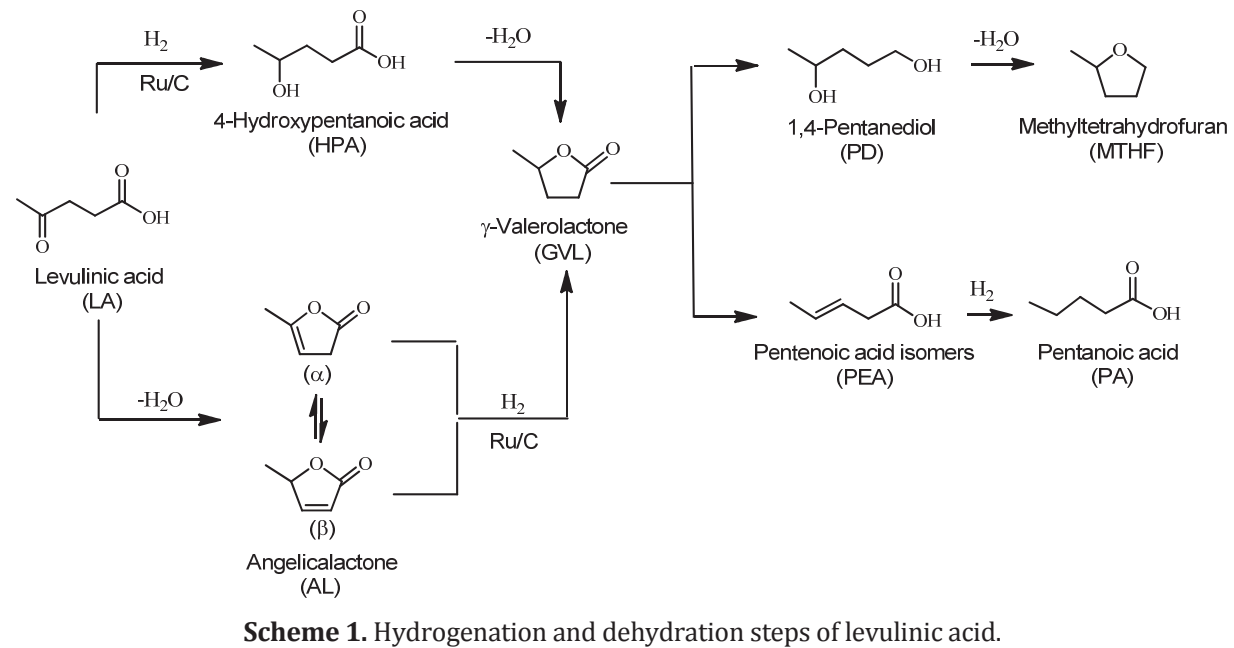

have been reported to show a good activity in levulic hydrogenation as reported for half-sandwich [17] or pincer complexes [18]. A computational study of this latter case evidenced two possible pathways: the first where the limiting rate step is the hydride transfer to give $\mathrm{La}-\mathrm{H}-$ and $\mathrm{LIrH}_{2}+$, the second where a trihydride iridium complex is formed [19].

Based on this finding we thought that a reducible oxide as $\mathrm{TiO}_{2}$ would have helped the activity of supported Ir particles as in the case of $\mathrm{MoO}_{x}$. Therefore herein we investigate in the reduction of levulinic acid to GVL, $\mathrm{Ir} / \mathrm{TiO}_{2}$ catalyst and investigated the effect of $\mathrm{Au}$ addition through sequential deposition-precipitation technique. We have previously fully characterized these catalysts and DFT calculations are also available providing us useful information about the interaction with the support $\left(\mathrm{TiO}_{2}\right)[20]$.

\section{Experimental}

Titania Evonik P25 was used as a support $\left(45 \mathrm{~m}^{2} / \mathrm{g}\right.$, nonporous $70 \%$ anatase, $30 \%$ rutile, purity $99.5 \%$ ). Commercial $\mathrm{HAuCl}_{4} \cdot 3 \mathrm{H}_{2} \mathrm{O}, \mathrm{IrCl}_{4} \cdot 4 \mathrm{H}_{2} \mathrm{O}$ and $\mathrm{RuCl}_{3}$ from Aldrich were used as gold, iridium and ruthenium precursors, respectively. Before preparation, $\mathrm{TiO}_{2}$ was dried in air at $100{ }^{\circ} \mathrm{C}$ for at least $24 \mathrm{~h}$. $\mathrm{NaBH}_{4}$ of purity $>96 \%$ from Fluka was used. Gaseous hydrogen from SIAD was $99.99 \%$ pure.

\subsection{Preparation of monometallic samples}

The preparation of the $1 \mathrm{wt} \% \mathrm{Au} / \mathrm{TiO}_{2}$ and $\mathrm{Ir} / \mathrm{TiO}_{2}$ sample was performed by deposition-precipitation with urea (DPU) in the absence of light, following a previously reported procedure [21-24].

The gold precursor $\mathrm{HAuCl}_{4}$ or the iridium precursor $\mathrm{IrCl}_{4}$ ( $4.2 \mathrm{mmol})$, and urea $(0.42 \mathrm{~mol})$ were dissolved in $50 \mathrm{~mL}$ of distilled water. Then, $1 \mathrm{~g}$ of titania was added to this solution. The suspension temperature was then increased to $80{ }^{\circ} \mathrm{C}$ and kept constant for $16 \mathrm{~h}$ under stirring. The samples were then washed with water and centrifuged four times, and dried under vacuum at $80{ }^{\circ} \mathrm{C}$ for $2 \mathrm{~h}$ and then calcined at $400{ }^{\circ} \mathrm{C}$ under $\mathrm{H}_{2}$ atmosphere for $1 \mathrm{~h}$. The samples were stored at room temper- ature away from light. The metal loading of $1 \mathrm{wt} \%$ was obtained.

Monometallic $1 \% \mathrm{Ru} / \mathrm{TiO}_{2}$ has been prepared by incipient wetness impregnation. Solid $\mathrm{RuCl}_{3}$ (equivalent to $\mathrm{Ru} 10 \mathrm{mg}$ ) was dissolved in water $(1.5 \mathrm{~mL})$ and added to $1 \mathrm{~g}$ of support (final ruthenium loading of $1 \mathrm{wt} \%$ ). The catalyst was then dried at $80^{\circ} \mathrm{C}$ for $2 \mathrm{~h}$ and reduced in $\mathrm{H}_{2}$ at $200^{\circ} \mathrm{C}$ for $2 \mathrm{~h}$.

\subsection{Preparation of bimetallic samples}

A sequential deposition method was used to prepare the bimetallic catalyst. Iridium was first deposited on $\mathrm{TiO}_{2}$ by deposition-precipitation with urea as described above. After drying at $80{ }^{\circ} \mathrm{C}$ for $2 \mathrm{~h}$, the $\mathrm{Ir} / \mathrm{TiO}_{2}$ sample was calcined in air at $500{ }^{\circ} \mathrm{C}$ for $2 \mathrm{~h}$ at a heating rate of $2{ }^{\circ} \mathrm{C} / \mathrm{min}$, before gold was deposited by deposition-precipitation. The same procedure of washing, drying and calcination as above was applied. The total loading of the metals was $1 \mathrm{wt} \%$ and the molar ratio $\mathrm{Au} / \mathrm{Ir}=1 / 1$. Chemical analysis of $\mathrm{Au}$ and $\mathrm{Ir}$ in the samples to determine the actual loadings was performed by X-ray fluorescence (XRF) using a spectrometer XEPOS HE (AMETEK). The Au and Ir mass loadings were expressed in grams of each metal per gram of the sample (Table 1).

The $\mathrm{Au}-\mathrm{Ru}$ was prepared following a sequential impregnation. A solution of $\mathrm{NaAuCl}_{4}$ was added to $0.27 \mathrm{wt} \% \mathrm{Ru} / \mathrm{TiO}_{2}$ prepared as above reported. After $3 \mathrm{~h}$ the catalyst was filtered, dried and then calcined as for the monometallic sample. The total metal loading was $1 \mathrm{wt} \%$ and the molar ratio $\mathrm{Au} / \mathrm{Ru}=$ $8 / 2$. The metal content was checked by ICP analysis of the filtrate using a Jobin Yvon JY24 instrument. Morphology of the catalysts was characterized in a Philips CM200 FEG electron

Table 1

Theoretical and actual Au and Ir loadings in the studied catalysts.

\begin{tabular}{lcccc}
\hline \multirow{2}{*}{ Sample } & \multicolumn{4}{c}{ Metal loading (wt\%) } \\
\cline { 2 - 5 } & Nominal Au & Actual Au & Nominal Ir & Actual Ir \\
\hline $\mathrm{Au} / \mathrm{TiO}_{2}$ & 1 & 1.1 & 0 & 0 \\
$\mathrm{Ir} / \mathrm{TiO}_{2}$ & 0 & 0 & 1.0 & 0.96 \\
$\mathrm{Au}-\mathrm{Ir} / \mathrm{TiO}_{2}$ & 0.5 & 0.57 & 0.5 & 0.5 \\
\hline
\end{tabular}


microscope, operating at $200 \mathrm{kV}$ and equipped with a Gatan imaging filter, GIF Tridiem.

\subsection{Catalytic test}

Levulinic acid (LA) hydrogenation was performed at $70{ }^{\circ} \mathrm{C}$, using a stainless steel reactor ( $50 \mathrm{~mL}$ capacity), equipped with heater, mechanical stirrer, gas supply system and thermometer. The LA solution ( $30 \mathrm{~mL} ; 0.3 \mathrm{~mol} / \mathrm{L})$ was added into the reactor and the desired amount of catalyst (LA/metal molar ratio $=1000$ ) was suspended in the solution. The autoclave was then purged three times with nitrogen before charging $0.7 \mathrm{MPa}$ of $\mathrm{H}_{2}$. The mixture was heated to the reaction temperature, 70 ${ }^{\circ} \mathrm{C}$, and mechanically stirred ( $\left.1250 \mathrm{r} / \mathrm{min}\right)$.

For product analysis, the reaction mixture, after separation from the catalysts by filtration, was analyzed using high performance liquid chromatography (HPLC). Samples were removed periodically $(0.5 \mathrm{~mL})$ under stirring and analyzed by HPLC using a column (Alltech OA-10308, $300 \mathrm{~mm} \times 7.8 \mathrm{~mm}$ ) with UV and refractive index (RI) detection in order to analyze the product mixtures. $\mathrm{H}_{3} \mathrm{PO}_{4}$ solution $(0.1 \mathrm{wt} \%)$ was used as the eluent. The identification of the possible products was done by comparison with the original samples.

In some cases an activation step was performed prior to the reaction and the catalyst was pre-reduced in the autoclave for 1 h at $150{ }^{\circ} \mathrm{C}$ under $0.3 \mathrm{MPa}$ of $\mathrm{H}_{2}$.

\section{Results and discussion}

The catalytic results of the monometallic sample are reported in Table 2. Monometallic Ir appeared very active, more than Ru. However, it presented a slight lower selectivity to GVL. The reductive pretreatment carried out in situ seems to have a beneficial effect restoring an almost full selectivity to GVL. The same pretreatment on $\mathrm{Ru} / \mathrm{TiO}_{2}$ showed a negligible effect, maintaining very similar activity and selectivity as without the pretreatment. Monometallic gold did not show any activity.

We already demonstrated that when depositing $\mathrm{Au}$ on $\mathrm{Ru}$ catalyst, a migration of $\mathrm{Ru}$ on $\mathrm{Au}$ occurred forming Au-core particles with enriched Ru-surface [15]. On the contrary, when depositing Au on Ir catalysts, a segregation of Ir atoms toward the $\mathrm{TiO}_{2}$ surface occurred. Au-Ir bimetallic particles are formed on top of Ir slags [20]. The two catalysts showed a very different catalytic behavior (Table 2). In particular the addition of $\mathrm{Au}$ to $\mathrm{Ir} / \mathrm{TiO}_{2}$ led to a drastic drop of the activity despite the small size of the metal particles (2.65 $\pm 1.07 \mathrm{~nm}$ [20]) and only $12 \%$ of levulinic acid conversion could be obtained after $6 \mathrm{~h}$ reaction. Pretreating the catalyst with $\mathrm{H}_{2}$ a slight increase of the conversion was observed (38\%) but still lower than the activity of $\mathrm{Ir} / \mathrm{TiO}_{2}$ (>99\%; Table 2). The presence of bimetallic Au-Ir species, however, promoted the selective formation of GVL as shown by the increasing of selectivity ( $>99$ ). On the contrary, $\mathrm{Au}-\mathrm{Ru} / \mathrm{TiO}_{2}$ showed an enhancement of the activity (conversion after $3 \mathrm{~h}=86 \%$; Table 2) with respect to monometallic, also maintaining the full selectivity to GVL. A representative TEM image with particle distribution is reported in Figure 1.

The real presence of bimetallic particles and the presence of synergism between $\mathrm{Au}$ and Ir (negative effect) or $\mathrm{Ru}$ (positive effect) was also studied by carrying out catalytic tests in the presence of physical mixture of the two catalysts: $\mathrm{Au} / \mathrm{TiO}_{2}+\mathrm{Ir} / \mathrm{TiO}_{2}$ or, alternatively, $\mathrm{Au} / \mathrm{TiO}_{2}+\mathrm{Ru} / \mathrm{TiO}_{2}$. In the first case the conversion reflected the composition of the mixture, i.e., consistent with the reduced amount of the active metal Ir. Moreover, the selectivity is basically the same as for monometallic iridium thus supporting the idea that no bimetallic species are formed within the reaction medium. On the contrary, in the case of $\mathrm{Au} / \mathrm{TiO}_{2}+\mathrm{Ru} / \mathrm{TiO}_{2}$ systems the conversion appeared higher than expected on the basis of the amount of the actually present $\mathrm{Ru}$ metal (i.e., calculated around 50\% instead of $73 \%$, Table 2). This finding can be explained by the in situ formation of alloyed species due probably, to the detachment of $\mathrm{Ru}$ particles from the $\mathrm{TiO}_{2}$ surface and the migration onto $\mathrm{Au}$ ones. This sort of migration, in the case of Ir, is probably neglected by the strong metal-support interaction of Ir with $\mathrm{TiO}_{2}$ established also by DFT calculations [20].

As reported in $[24,25] \mathrm{Au}-\mathrm{Ir} / \mathrm{TiO}_{2}$ showed a higher activity than monometallic ones in the case of CO oxidation as well as in the total oxidation of propene [26]. The synergistic effect was addressed to a hindered reoxidation of Ir and the establishment of $\mathrm{Au}^{0}-\mathrm{Ir}^{0}$ interaction. Indeed XPS spectra in bimetallic sample showed the absence of the typical contribution of $\mathrm{Ir}^{4+}$ peak due to the reoxidation of $\operatorname{Ir}^{0}$ exposed to air [26]. In the monometal-

Table 2

Levulinic acid hydrogenation with monometallic and bimetallic catalysts after $3 \mathrm{~h}$ and $6 \mathrm{~h}$ reaction.

\begin{tabular}{|c|c|c|c|c|}
\hline \multirow{2}{*}{ Catalyst } & \multicolumn{2}{|c|}{ Conversion (\%) } & \multicolumn{2}{|c|}{ Selectivity to GVL (\%) } \\
\hline & $3 \mathrm{~h}$ & $6 \mathrm{~h}$ & $3 \mathrm{~h}$ & $6 \mathrm{~h}$ \\
\hline $1 \mathrm{wt} \% \mathrm{Ir} / \mathrm{TiO}_{2}$ & 91 & $>99$ & 94 & 97 \\
\hline $1 \mathrm{wt} \% \mathrm{Ir} / \mathrm{TiO}_{2}$ pretreated in situ & 74 & $>99$ & $>99$ & $>99$ \\
\hline $1 \mathrm{wt} \% \mathrm{Ru} / \mathrm{TiO}_{2}$ & 62 & 90 & $>99$ & $>99$ \\
\hline $1 \mathrm{wt} \% \mathrm{Ru} / \mathrm{TiO}_{2}$ pretreated in situ & 52 & 95 & $>99$ & $>99$ \\
\hline $1 \mathrm{wt} \% \mathrm{Au} / \mathrm{TiO}_{2}$ & - & $<1$ & - & - \\
\hline $1 \mathrm{wt} \% \mathrm{Au}-\mathrm{Ir} / \mathrm{TiO}_{2}$ & 4 & 12 & $>99$ & $>99$ \\
\hline $1 \mathrm{wt} \% \mathrm{Au}-\mathrm{Ir} / \mathrm{TiO}_{2}$ pretreated in situ & 26 & 38 & $>99$ & $>99$ \\
\hline $1 \mathrm{wt} \% \mathrm{Au}-\mathrm{Ru} / \mathrm{TiO}_{2}$ & 86 & $>99$ & $>99$ & $>99$ \\
\hline $1 \mathrm{wt} \% \mathrm{Au}-\mathrm{Ru} / \mathrm{TiO}_{2}$ pretreated in situ & 70 & $>99$ & $>99$ & $>99$ \\
\hline $1 \mathrm{wt} \% \mathrm{Au} / \mathrm{TiO}_{2}+1 \mathrm{wt} \% \mathrm{Ir} / \mathrm{TiO}_{2}(1: 1)^{*}$ & 33 & 48 & 94 & 98 \\
\hline $1 \mathrm{wt} \% \mathrm{Au} / \mathrm{TiO}_{2}+1 \mathrm{wt} \% \mathrm{Ru} / \mathrm{TiO}_{2}(4: 1) *$ & 73 & 98 & $>99$ & $>99$ \\
\hline
\end{tabular}

Reaction conditions: $\mathrm{LA}=0.3 \mathrm{~mol}$; metal $/ \mathrm{LA}=1 / 1000(\mathrm{~mol} / \mathrm{mol}), p\left(\mathrm{H}_{2}\right)=0.5 \mathrm{MPa}, 70^{\circ} \mathrm{C}$.

* Physical mixture. 

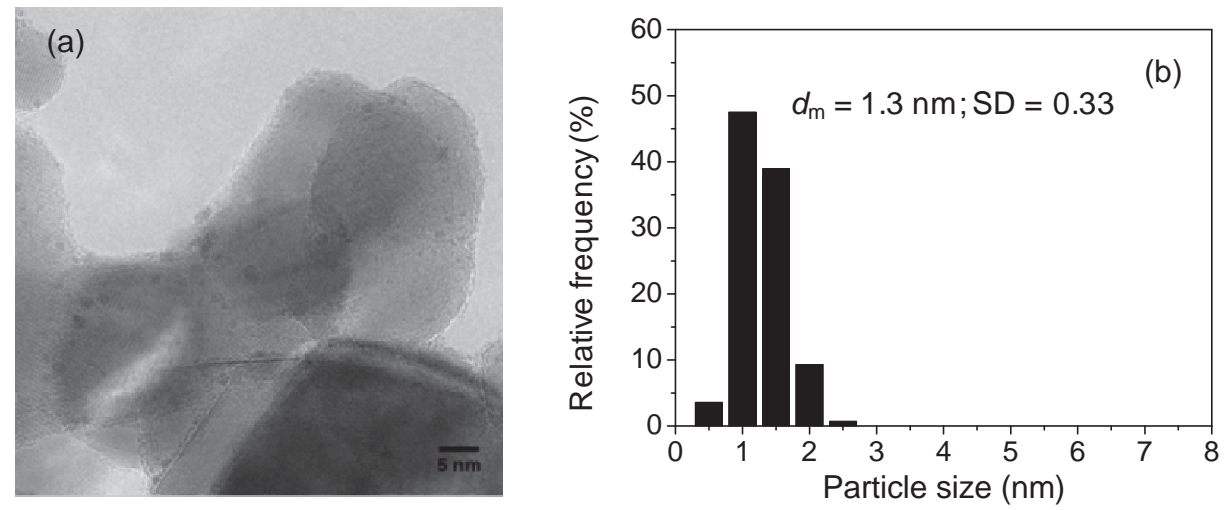

Fig. 1. (a) Representative TEM image and (b) particle size distribution of $\mathrm{Au}-\mathrm{Ru} / \mathrm{TiO}_{2}$.

lic sample this latter peak constitutes the main one of Ir. Under reducing conditions the $\mathrm{Au}^{0}-\mathrm{Ir}^{0}$ interactions are obviously still present, and therefore we have to address the negative synergistic effect to the Au interference into the redox mechanism of Ir atoms. Under reducing conditions the redox cycle of the metal could be even more influenced by the difficulty of the Ir to be oxidized representing the first elemental step of the reaction (Scheme 1). Previous study on CO chemisorption followed by DRIFT spectra supported the finding that alloying gold to iridium would result in the disappearance of contiguous Ir sites [26]. We thus might conclude that the interference in the redox cycle at the base of the catalytic activity is mostly due to this isolation of Ir sites.

\section{Conclusions}

We have tested and compared the activity of $\mathrm{Ir} / \mathrm{TiO}_{2}$, $\mathrm{Ru} / \mathrm{TiO}_{2}$ and bimetallic catalysts $\mathrm{Au}-\mathrm{Ir} / \mathrm{TiO}_{2}$ and $\mathrm{Au}-\mathrm{Ru} / \mathrm{TiO}_{2}$ in the levulinic acid hydrogenation. The bimetallic catalysts were prepared following a two steps procedure. Both catalysts pre- sented a bimetallic structure but Ir provided a stronger metal-support interaction with $\mathrm{TiO}_{2}$ compared to $\mathrm{Ru}$. This will be beneficial for the stabilization of the metals onto the support. However, in the case of iridium, the addition of gold lowered the activity of the catalyst even if it enhanced the selectivity to GVL. A possible reason of the detrimental effect of Au on Ir catalyst is the electronic interaction between the two metals, which apparently affected the redox cycle of Ir. The possible presence of isolated Ir site could be at the origin of this effect.

\section{Acknowledgments}

R. Zanella acknowledge the financial support granted by project UNAM-PAPIIT IN105416. We acknowledge V. Maturano for Au-Ir samples preparation.

\section{References}

[1] M. Besson, P. Gallezot, C. Pinel, Chem. Rev., 2014, 114, 1827-1870.

[2] M. J. Climent, A. Corma, S. Iborra, Green Chem., 2014, 16, 516-547.

\section{Graphical Abstract}

Chin. J. Catal., 2016, 37: 1771-1775 doi: 10.1016/S1872-2067(16)62512-3

\section{Gold-iridium catalysts for the hydrogenation of biomass derived products}

Lorenzo Landenna, Alberto Villa, Rodolfo Zanella, Claudio Evangelisti, Laura Prati* Università degli Studi di Milano, Italy; Universidad Nacional Autonoma de Mexico, Mexico; Istituto di Scienze e Tecnologie Molecolari ISTM-CNR, Italy

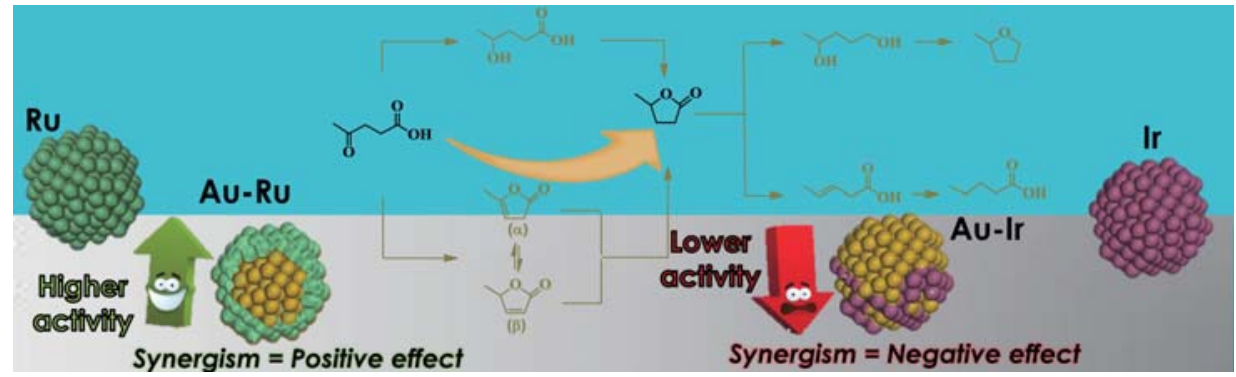

Gold as a modifier of Ir catalyst was studied in levulinic acid hydrogenation to $\gamma$-valerolactone. Differently from the case of Ru, the bimetallic Au-Ir catalyst showed a lower activity with respect to monometallic despite a higher selectivity. 
[3] W. R. H. Wright, R. Palkovits, ChemSusChem, 2012, 5, 1657-1667.

[4] J. Q. Bond, D. M. Alonso, D. Wang, R. M. West, J. A. Dumesic, Science, 2010, 327, 1110-1114.

[5] J. Q. Bond, D. M. Alonso, D. Wang, R. M. West, J. A. Dumesic, J. Catal., 2011, 281, 290-299.

[6] J. C. Serrano-Ruiz, D. J. Braden, R. M. West, J. A. Dumesic, Appl. Catal. B, 2010, 100, 184-189.

[7] I. T. Horvath, H. Mehdi, V. Fabos, L. Boda, L. T. Mika, Green Chem., 2008, 10, 238-242.

[8] D. M. Alonso, S. G. Wettstein, J. A. Dumesic, Green Chem., 2013, 15, 584-595.

[9] V. Swarna Jaya, M. Sudhakar, S. Naveen Kumar, A. Venugopal, RSC Adv., 2015, 5, 9044-9049.

[10] A. M. Hengne, C. V. Rode, Green Chem., 2012, 14, 1064-1072.

[11] L. E. Manzer, Appl. Catal. A, 2004, 272, 249-256.

[12] W. H. Luo, P. C. A. Bruijnincx, B. M. Weckhuysen, J. Catal., 2014, 320, 33-41.

[13] A. M. R. Galletti, C. Antonetti, V. De Luise, M. Martinelli, Green Chem., 2012, 14, 688-694.

[14] A. Villa, M. Schiavoni, C. E. Chan-Thaw, P. F. Fulvio, R. T. Mayes, S. Dai, K. L. More, G. M. Veith, L. Prati, ChemSusChem, 2015, 8, 2520-2528.
[15] A. Villa, C. E. Chan-Thaw, S. Campisi, C. L. Bianchi, D. Wang, P. G. Kotula, C. Kuebel, L. Prati, Phys. Chem. Chem. Phys., 2015, 17, 28171-28176.

[16] Z. Q. Wang, G. Y. Li, X. Y. Liu, Y. Q. Huang, A. Q. Wang, W. Chu, X. D. Wang, N. Li, Catal. Commun., 2014, 43, 38-41.

[17] T. P. Brewster, A. J. M. Miller, D. M. Heinekey, K. I. Goldberg, J. Am. Chem. Soc., 2013, 135, 16022-16025.

[18] W. Li, J. H. Xie, H. Lin, Q. L. Zhou, Green Chem., 2012, 14, 2388-2390.

[19] H. Gao, J. Z. Chen, J. Organomet. Chem., 2015, 797, 165-170.

[20] C. W. Han, P. Majumdar, E. E. Marinero, A. Aguilar-Tapia, R. Zanella, J. Greeley, V. Ortalan, Nano Lett., 2015, 15, 8141-8147.

[21] R. Zanella, L. Delannoy, C. Louis, Appl. Catal. A, 2005, 291, 62-72.

[22] R. Zanella, S. Giorgio, C. R. Henry, C. Louis, J. Phys. Chem. B, 2002, 106, 7634-7642.

[23] R. Zanella, C. Louis, Catal. Today, 2005, 107-108, 768-777.

[24] A. Gomez-Cortes, G. Diaz, R. Zanella, H. Ramırez, P. Santiago, J. M. Saniger, J. Phys. Chem. C, 2009, 113, 9710-9720.

[25] X. Bokhimi, R. Zanella, C. Angeles-Chavez, J. Phys. Chem. C, 2010, 114, 14101-14109.

[26] A. Aguilar-Tapia, R. Zanella, C. Calers, C. Louis, L. Delannoy, Phys. Chem. Chem. Phys., 2015, 17, 28022-28032.

\title{
Au-Ir催化剂用于生物质衍生物加氢
}

\author{
Lorenzo Landenna $^{\text {a }}$, Alberto Villa ${ }^{\text {a }}$, Rodolfo Zanella ${ }^{\mathrm{b}}$, Claudio Evangelisti ${ }^{\mathrm{c}}$, Laura Prati ${ }^{\mathrm{a} *}$ \\ a米兰大学化学系, 米兰20133, 意大利 \\ $\mathrm{b}^{\mathrm{b}}$ 墨西哥国立自治大学科学应用与技术开发中心, 墨西哥城04510, 墨西哥 \\ c 意大利国家研究委员会分子科学技术研究所, 米兰20138, 意大利
}

摘要: 采用沉积-沉淀法制备了 $\mathrm{TiO}_{2}$ 负载的 $\mathrm{Au}-\mathrm{Ir}$ 和 $\mathrm{Au}-\mathrm{Ru}$ 催化剂, 用于乙酰丙酸加氢制 $\gamma$-戊内酯反应, 并与相应的单金属催 化剂性能进行了比较. 有趣的是, $\mathrm{Ir}_{\mathrm{T}} \mathrm{TiO}_{2}$ 中添加 $\mathrm{Au}$ 抑制了催化剂活性, 而添加 $\mathrm{Ru}$ 则表现出正效应的协同作用. 这两个催化 剂均在 $\mathrm{H}_{2}$ 中还原, 使得 $\mathrm{M}^{0}-\mathrm{Au}^{0}$ 间相互作用增强. 结合以前的密度泛函理论计算和催化反应结果, 我们认为, $\mathrm{Au}-\mathrm{Ir} / \mathrm{TiO} \mathrm{O}_{2}$ 催化 剂活性低于 $\mathrm{Ir} / \mathrm{TiO}_{2}$ 催化剂是由于 $\mathrm{Au}$ 影响了 $\mathrm{Ir}$ 原子的氧化还原过程.

关键词: 乙酰丙酸加氢; 金-铱催化剂; 金-钉催化剂; $\gamma$-戊内酯; 协同效应

收稿日期: 2016-05-11. 接受日期: 2016-07-09. 出版日期: 2016-10-05.

*通讯联系人. 电话: +3902503 14357; 传真: +3902503 14405; 电子信箱:_Laura.Prati@unimi.it

本文的英文电子版由Elsevier出版社在ScienceDirect上出版(http://www.sciencedirect.com/science/journal/18722067). 